\title{
Madde Kullanan Ergenlerde Psikiyatrik Eș Tanı, Bağımlılık Profili ve Tedavi İsteği: ÇEMATEM Verileri
}

\author{
Psychiatric Comorbidity, Addiction Profile and Desire for Treatment in Substance- \\ Using Adolescents: ÇEMATEM Data
}

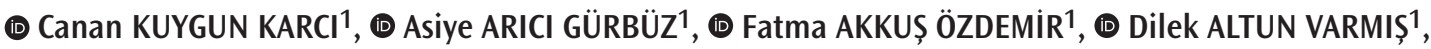 \\ (1) Ayșegül YOLGA TAHIROĞLU1
}

${ }^{1}$ Adana Dr. Ekrem Tok Ruh Sağlığı ve Hastalıkları Hastanesi, Adana, Türkiye

\section{$\ddot{\mathrm{O} z}$}

Amaç: Ergenlerde madde kullanımı, tüm dünyada olduğu gibi ülkemizde de önemli bir sorun olmaya devam etmektedir. Bu çalışma ile ergenlerde madde kullanımının özellikleri, eșlik eden psikiyatrik tanılar, bağımlılık profili, maddeyi bırakma ve tedavi olma isteğinin incelenmesi amaçlanmıştır. Yöntem: Çocuk ve Ergen Madde Bağımlıı̆̆ı Tedavi Merkezi (ÇEMATEM) polikliniğine başvuran 50 ergen çalışmaya dahil edildi. Ergenlerin psikiyatrik tanıları için Okul Çağı Çocukları için Duygulanım Bozuklukları ve şizofreni Görüşme Çizelgesi-şimdi ve Yaşam boyu şekli DSM-5 (ÇDŞG-ŞY-DSM-5-T) kullanıldı. Madde kullanımı ile ilişkili veriler için Bağımlılık profil indexi ergen formu (BAPi-E), DSM-5 Düzey-2 madde kullanım ölçeği ve Değişime Hazır Olma ve Tedavi İsteği Ölçeği (SOCRATES) kullanıldı.

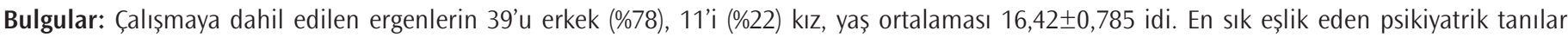
davranım bozukluğu (\%70), dikkat eksikliği hiperaktivite bozukluğu (DEHB) (\%38) ve depresyondu (\%10). Ergenlerin hepsi sigara (\%100), \%72'si esrar, \%56’sı alkol, \%34'ü metamfetamin ve \%26’sı ekstazi kullanmaktaydı. Ergenlerin \%90'ı madde kullanmaya arkadaş aracılığı ile başladığını bildirdi. 11 ergenin idrar testinde madde pozitif saptandı. Madde kullanan ergenlerin \%68'inin okula devam etmediği, okula devam eden madde kullanan ergenlere göre daha şiddetli madde isteği bildirdikleri gözlendi. Ergenlerde yaş ve bağımlılık şiddeti arttıkça maddeyi bırakma ve tedavi olma isteğinin arttığı saptandı.

Sonuç: Madde kullanan ergenler arasında okulu bırakma, psikiyatrik eş tanı ve madde kullanan arkadaş çevresinin sık olduğu çalışma bulgularımız ile desteklenmiştir. Bu nedenle riskli gruplara yapılacak uygun müdahaleler ile hem madde kullanımına başlanmasının önlenmesi hem de madde kullanan ergenlerin bırakma ve tedavi olma isteğinin arttırılması amaçlanmalıdır.

Anahtar kelimeler: Madde kullanımı, ergenlik, sigara, esrar, alkol

\section{Abstract}

Objective: Substance use among adolescents continues to be an important problem in our country as in the rest of the world. The aim of this study was to examine the characteristics of substance use in adolescents, psychiatric diagnoses, addiction profile, and treatment eagerness.

Method: Fifty adolescents who applied to ÇEMATEM outpatient clinic were included in the study. For the psychiatric diagnoses of adolescents, affective disorders and schizophrenia interview schedule for school-age children-present and lifetime DSM-5 (K-SADS-PL-DSM-5-T) was used. For data related to substance use, the addiction profile index adolescent form (BAPI-E), DSM-5 Level-2 substance use scale and the State of Change Readiness and Treatment Eagerness Scale (SOCRATES) were used.

Results: 39 of the adolescents included in the study were boys (78\%), 11 (22\%) girls, with an average age of $16.42 \pm 0.785$. The most common comorbid psychiatric diagnoses were conduct disorder (70\%), ADHD (38\%) and depression (10\%). All of the adolescents were using cigarettes (100\%), $72 \%$ cannabis, $56 \%$ alcohol, $34 \%$ methamphetamine and $26 \%$ ecstasy. $90 \%$ of the adolescents stated that they started using substances through their friends. The substance was found positive in the urine test of 11 adolescents. It was observed that $68 \%$ of the adolescents who used substances did not attend school and reported more severe substance cravings compared to the adolescents who continued to school. It was found that as the age and the severity of addiction increased, the change readiness and treatment eagerness increased. 
Conclusion: The prevalence of school dropout, psychiatric comorbidity and substance-using friends among adolescents with substance use is supported by our study findings. For this reason, it should be aimed to prevent the initiation of substance use and to increase the willingness of adolescents to quit and seek treatment with appropriate interventions to risky groups.

Keywords: Substance use, adolescence, tobacco, cannabis, alcohol

\section{Giriş}

Ergenlik, beynin ödül sistemi ve dürtüsel davranışlarla ilișkili bölgelerinde farklılașmaların yașandığı, oldukça kritik bir gelişim dönemidir. Bu farklılașmaların sonucu olarak yenilik arayıșı ve risk alan davranışlarda artış gözlenmektedir $(1,2)$. Madde kullanımı tipik olarak ergenlikte bașlar (3) ve bunun yetișkinlikte bağımlılık gelişimi için bir risk faktörü olduğu bilinmektedir (4). Ergenlikte madde kullanımının eșlik eden psikopatoloji gelișimi, düșük akademik başarı, nörokognitif bozulmalar ve sosyal alanda sorunlar gibi pek çok olumsuz sonuçları olabilmektedir (5-7).

Madde ile tanışan ergenlerin bir kısmı deneme veya problemli kullanım düzeyinde kalabilse de \%5'i madde kullanım bozukluğu tanı kriterlerini karșılamaktadır (8). Bireysel, ailesel ve çevresel bazı faktörlerin madde ile ilișkili problem yaşama riskini arttırdığı bilinmektedir. Ailede madde kullanım bozukluğu öyküsü, erkek cinsiyet, madde kullanan arkadașlar, travmatik erken yaşam olayları ve zayıf ebeveyn kontrolü önemli risk faktörlerinin bașında gelmektedir $(7,9,10)$. Ek olarak, dikkat eksikliği hiperaktivite bozukluğu (DEHB), depresyon ve davranım bozukluğu gibi psikiyatrik eș tanısı olan ergenlerin alkol ve madde bağımlılı̆ı açısından daha yüksek riske sahip oldukları gösterilmiștir (11-13).

Genel nüfusta madde kullanma öyküsü Avrupa'ya kıyasla daha düşük oranda olsa da, ülkemizde madde kullanımı ciddi bir sorun olușturmakta ve yıllar içerisinde artış göstermektedir. Ülkemizde genel nüfusta tütün ürünü kullanma oranı \%47, ilk kez tütün ürünü deneme yaşı ortalaması 17,85; alkol kullanma oranı \%22,1, ilk kez alkol deneme yașı ortalama 19,94; madde kullanma oranı \%3,1, ilk kez madde kullanım yaș ortalaması 19 olarak bildirilmiştir (14). Türkiye'de haklarında uyuşturucu suçlarından dolayı ișlem yapılan kişilerle yapılan anket çalışmasının 2019 yılı verilerine göre; \%7,3'ünün 15 yaşından önce, \%71,2'sinin ise 15-24 yaș aralığında madde kullanmaya bașladığı öğrenilmiş̦tir (15). Aynı grupta uyuşturucu madde kullanımı öncesi tütün kullanım oranı \%81, tütüne bașlama yașı ortalaması 15,98; uyuşturucu madde kullanım öncesi alkol kullanma oranı ise \%38, alkole başlama yaşı ortalaması 17,77 olarak bildirilmiştir (15).

Ülkemizde çocuk ve ergenlerde sigara, alkol ve madde kullanımı ile ilgili araștırmalar oldukça kısıtlı sayıda bulunmaktadır. 2011 yılında yapılan okul çocukları çalıșmasında, yaşam boyu madde kullanım sıklığı \%1,5, maddeyi ilk kullanma yaşı ortalaması 13,88 olarak bildirilmiștir (16). 2014 yılında ìstanbul ilinde yapılan çalışmada 10 .sınıf öğrencilerinin \%34,2'si alkolü, \%24,4'ü sigarayı, \%4,9'u uçucu maddeleri, \%3,8'i benzodiazepinleri, \%2,9'u esrarı ve \%0,4'ü eroini en az bir kez denediğini bildirmiștir (17). Ülkemizde Çocuk ve ergen madde bağımlılığı tedavi merkezi (ÇEMATEM) klinikleri kısıtlı sayıda olsa da çocuk ve ergenlerin madde kullanımı açısından risk faktörlerinin iyi bilinmesi, çocuk psikiyatri polikliniklerine başvuran riskli hastalara gerekli müdahalelerin yapılmasına fayda sağlayacaktır. Bu çalıșma ile bir ayaktan ÇEMATEM polikliniğine başvuran ergenlerin sosyodemografik özellikleri, psikiyatrik eș tanı, madde kullanım özellikleri ve tedavi motivasyonlarını değerlendirilmesi amaçlanmıştır.

\section{Yöntem}

\section{Örneklem}

Çalıșmaya Şubat 2020 tarihinden sonra hastanemiz ayaktan ÇEMATEM polikliniğine başvuran, madde kullandığını ifade eden ve/veya laboratuvar test sonucunda madde pozitifliği olan 50 ergen ve ebeveyni dahil edilmiştir. ÇEMATEM polikliniğimiz yalnızca ayaktan hizmet vermekte olup, randevusuz şekilde hafta içi her gün başvuru kabul etmektedir. Başvuran tüm hastalar önce idrar testi vermekte, test sonucu ile çocuk ve ergen psikiyatri uzmanı tarafından değerlendirilmektedir. Denetimli serbestlik kararı olan ergenler hastanemiz bünyesindeki diğer merkezde değerlendirilmektedir. Çalışmaya madde kullandığını ifade eden ve tedavi olma amacı ile başvurmuş ergenler dahil edilmiş olup, madde kullanım şüphesi ile ailesi tarafından getirilen, madde kullanmadığını söyleyen ve idrar testi negatif olan ergenler çalışmaya dahil edilmemiştir. Otizm, mental retardasyon ve okuryazar olmama dışlanma kriterleri arasında yer almıştır. Şubat 220 tarihinde başlanan çalışma, dahil edilme kriterlerine uyan ve onam veren 50 ergen tamamlandığında sonlandırılmıştır.

\section{İşlem}

Tüm ergenler, çocuk ve ergen psikiyatri uzmanı tarafından Okul Çağı Çocukları için Duygulanım Bozuklukları ve Șizofreni Görüșme Çizelgesi-şimdi ve Yaşam boyu şekli DSM-5 (ÇDŞG-ŞY-DSM-5-T) (18) kullanılarak psikiyatrik eş tanı açısından değerlendirilmiş̧tir. ÇDŞG-ŞY-DSM-5-T görüşmeci tarafından uygulanan, 23 farklı tanı alanında değerlendirme yapmaya imkan veren kapsamlı bir değerlendirme aracıdır. 
Olguların sosyodemografik verileri araștırmacılar tarafından hazırlanan form ile elde edilmiștir. Bu formda ergenin yaș, cinsiyet, eğitim durumu, yaşadığı yer, anne-babanın eğitim durumu, çalıșma durumu ve birlikteliği soruları yer almaktadır. Madde kullanımı ile ilișkili veriler için Bağımlııı profil indexi ergen formu (BAPI-E), DSM-5 Düzey-2 madde kullanım ölçeği ve Değişime hazır olma ve tedavi isteği ölçeği (SOCRATES) kullanılmıştır. Bu ölçekler ergen tarafından doldurulmuştur. ÇEMATEM'e başvuran tüm ergenlere idrarda madde testi yapılmaktadır. Çalıșmaya katılan tüm ergenlerden ve ebeveynlerinden yazılı onam alınmıștır. Calıșmanın etik kurul onayı Adana Şehir Eğitim ve Araștırma Hastanesi Klinik Araștırmalar Etik Kurulu'ndan alınmıștır (08.01.2020/669).

\section{Veri Toplama Araçları}

\section{Bağımlılık Profil İndexi Ergen formu (BAPI-E)}

Ögel ve ark. tarafından geliștirilen ve geçerlik-güvenirliği yapılan bu ölçek, 25 soru ve 5 alt ölçekten oluşmaktadır (19). Madde kullanım (madde kullanım özellikleri), tanı (bağımlılık tanı ölçütleri), yașam üstüne etkileri (madde kullanımının kișinin yașamına etkisi), șiddetli istek (șiddetli madde kullanma isteği) ve motivasyon (madde kullanımını bırakma motivasyonu) alt ölçek puanları ile BAPI toplam puanı (bağımlılık șiddeti) elde edilmektedir. Bağımlıı̆ı̆ boyutlarını değerlendirmekte ve bağımlıı̆̆ın şiddetini ölçmektedir. 12 puan altı düşük bağımlılık șiddeti, 12-14 puan arası orta, 14 üzeri puan yüksek bağımlııı şiddetini göstermektedir.

\section{DSM-5 Düzey-2 Madde Kullanım Ölçeği}

Ölçeğin 6-17 yaş için ebeveyn formu, 11-17 yaș için ergen formu bulunmaktadır. Ölçekteki her bir madde 5- noktalı bir skala üzerinde derecelendirilmektedir $(0=$ hiç, $1=$ bir ya da iki günden az, 2= birkaç gün, $3=$ günlerin yarısından çoğunda, $4=$ hemen her gün). Ebeveyn formu ayrıca "Bilmiyorum" seçeneğini de içermektedir. Ölçeğin Türkçe geçerlik ve güvenirlik çalışması Sapmaz ve ark. (20) tarafından yapılmıştır. Ölçek çocuk ve ergenlerin alkol, sigara/nikotin, reçetelenen ilaç ve yasadışı madde kullanımını değerlendirmektedir. Birden çok maddenin sıfırdan büyük derecelendirilmesi, madde kullanımının daha şiddetli olduğunu göstermektedir.

\section{Değişime Hazır Olma ve Tedavi İsteği Ölçeği (SOCRATES)}

Değişim için hazır olmayı ve tedavi motivasyonunu değerlendirmek için hazırlanan ölçeğin 16 maddelik Türkçe formunun hem alkol hem madde kullananlar için geçerlik ve güvenirliği yapılmıştır (21). Adım atma, farkına varma ve ikilem olmak üzere 3 alt ölçek puanı elde edilmektedir. (Cronbach alfa değeri: 0,84 )

\section{Veri Analizi}

İstatistiksel analizler, SPSS 22 yazılımı kullanılarak yapıldı. Değișkenlerin normal dağılıma uygunluğu analitik yöntemlerle
(Kolmogorov-Smirnov/Shapiro-Wilk testleri) kullanılarak incelendi. Tanımlayıcı analizler normal dağılan değișkenler için ortalama \pm std. sapma ve normal dağılmayanlar için median (IQR) min-maks olarak verildi. Demografik özellikler frekans ve yüzde değerleri verilerek tanımlayııı istatistikleri yapııdı. Sürekli verilerde, ikili grupları karşılaștırmak için normal dağııımda bağımsız gruplarda t-testi normal dağılım göstermeyen değişkenlerde Mann-Whitney $U$ testi kullanıldı. Kategorik verilerin analizinde Pearson Ki Kare veya Fisher's Kesin Ki kare test kullanıldı. Ölçekler ve alt ölçekler arasındaki ilişki Pearson's ve Spearman's rho korelasyon testi ile incelendi. $p$ değerinin 0,05 'in altında olduğu durumlar istatistiksel olarak anlamlı kabul edildi.

\section{Bulgular}

Çalıșmaya dahil edilen ergenlerin 39'u erkek (\%78), 11'i (\%22) kız idi. Yaş aralığı 14-17, yaş ortalaması 16,42 $\pm 0,785$ idi. Ergenlerin 2'si (\%4) ortaokula, 14'ü (\%28) liseye devam etmekte iken; 9'u (\%18) ilkokul terk, 10'u (\%20) ortaokul terk ve 15’i (\%30) lise terk idi. Ortalama kardeș sayısı 3,48 $\pm 2,06$ idi. Annelerin \%54'ü, babaların ise \%64'ü ilkokul mezunu idi. Annelerin \%94'ü ev hanımı, babaların \%20'si çalışmıyordu. Anne-babaların \%80'i evli ve birlikte yaşıyordu. Sosyodemografik veriler Tablo 1'de gösterilmiștir. Ergenlerin 35'inde (\%70) davranım bozukluğu, 19'unda (\%38) DEHB, 5'inde (\%10) depresif bozukluk, 2'sinde (\%4) sosyal fobi, 1'inde (\%2) yaygın anksiyete bozukluğu ve 1'inde (\%2) maddeye bağlı psikotik bozukluk eș tanıları saptandı.

Çalıșmadaki ergenlerin 28’i (\%56) alkol, tümü (\%100) sigara kullanmakta idi. Her gün alkol kullanan 2 (\%4), haftada1-3 kez kullanan 16 (\%32) iken 49 (\%98) ergen her gün sigara kullanmakta idi. Ergenlerin 49'u (\%98) madde kullandığını ifade ederken 1 ergen (\%2) kullanmadığını söylüyordu ancak idrar testinde madde pozitif idi. Toplamda 11 ergenin (\%22) idrar testinde madde pozitif saptandı. Pozitif olan maddeler; amfetamin 7 ergende (\%14), sentetik tetrahidrokannabinol (THC) 2 (\%4), benzodiazepin $1(\% 2)$ ve opiyat 1 ergende (\%2) pozitif

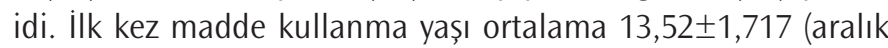
10-17 yaş) idi. Madde kullanmaya devam etme süresi ortalama $3 \pm 1,498$ yıl (aralık 1-7 yıl) olarak saptandı. Kırk beş ergen (\%90) madde kullanmaya arkadaş önerisi ile bașladığını belirtirken, ilk kullandıkları madde 35 ergende (\%70) sigara, 15 ergende (\%30) esrar idi. Şu anda sigara dışında kullanılan maddeler arasında en sık esrar (\%72) ve metamfetamin (\%34) yer almaktaydı. Ergenlerin hepsi çoklu madde kullanmaktaydı. Madde kullanımına ilișkin veriler Tablo 2'de yer almaktadır.

Kullanılan madde açısından bakıldı̆̆ında, eroin kullananlarda BAPi-E madde kullanım özellikleri $(p=0,034)$, tanı $(p=0,046)$, yaşam üzerine etkileri $(p=0,042)$, şiddetli istek $(p=0,005)$ ve toplam puanları $(p=0,007)$ anlamlı olarak daha yüksekti $(p<0,05)$. Alkol kullananlarda DSM-5 Düzey-2 madde kullanım ölçeği ergen $(p=0,038)$ ve ebeveyn $(p=0,029)$ ölçek puanları, 
BAPI-E madde kullanım özellikleri $(p=0,038)$ ve tanı $(p=0,021)$ alt ölçek puanları alkol kullanmayanlara göre anlamlı olarak daha yüksekti. Diğer madde türlerinde kullananlar ile kullanmayanlar arasında ölçek puanlarında anlamlı bir fark yoktu.

\begin{tabular}{|c|c|c|c|}
\hline & & $\mathrm{N}$ & $\%$ \\
\hline \multirow[t]{2}{*}{ Cinsiyet } & Kız & 11 & 22 \\
\hline & Erkek & 39 & 78 \\
\hline \multicolumn{4}{|l|}{ Eğitim durumu } \\
\hline & Ortaokul & 2 & 4 \\
\hline & Lise & 14 & 28 \\
\hline & İlkokul terk & 9 & 18 \\
\hline & Ortaokul terk & 10 & 20 \\
\hline & Lise terk & 15 & 30 \\
\hline \multirow[t]{5}{*}{ Anne eğitim durumu } & Okur yazar değil & 12 & 24 \\
\hline & İlkokul & 27 & 54 \\
\hline & Ortaokul & 4 & 8 \\
\hline & Lise & 5 & 10 \\
\hline & Üniversite & 2 & 4 \\
\hline \multicolumn{4}{|l|}{ Baba eğitim durumu } \\
\hline & Okur yazar değil & 6 & 12 \\
\hline & İlkokul & 32 & 64 \\
\hline & Ortaokul & 8 & 16 \\
\hline & Lise & 4 & 8 \\
\hline \multicolumn{4}{|l|}{ Anne çalışma durumu } \\
\hline & Ev hanımı & 47 & 94 \\
\hline & Memur & 2 & 4 \\
\hline & Emekli & 1 & 2 \\
\hline \multicolumn{4}{|l|}{ Baba çalışma durumu } \\
\hline & Esnaf & 7 & 14 \\
\hline & Memur & 4 & 8 \\
\hline & İş̧̧i & 27 & 54 \\
\hline & Emekli & 2 & 4 \\
\hline & Çalışmıyor & 10 & 20 \\
\hline \multicolumn{4}{|l|}{ Anne-baba birlikteliği } \\
\hline & Evli & 40 & 80 \\
\hline & $\begin{array}{l}\text { Boşanmıș/ } \\
\text { parçalanmış }\end{array}$ & 10 & 20 \\
\hline \multicolumn{4}{|l|}{ Yaşanılan yer } \\
\hline & Kentsel & 42 & 84 \\
\hline & Kırsal & 8 & 16 \\
\hline
\end{tabular}

Ergenin eğitim durumu ile ölçekler kıyaslandığında, lise/ ortaokul/ilkokul terk olanlarda BAPi-E şiddetli istek alt ölçek puanı okula devam edenlere göre anlamlı olarak daha yüksekti $(p=0,036)$. Diğer alt ölçek puanlarından anlamlı fark saptanmadı. Hem annenin hem babanın eğitim durumu ile ölçek puanları karşılaşııııldığında anlamlı fark yoktu. Cinsiyet ve psikiyatrik eş tanı açııından ölçek puanları arasında istatistiksel olarak anlamlı fark yoktu.

Ergenlerin yașı ile SOCRATES ölçeği ikilem $(r=0,528, p<0,001)$, adım atma ( $r=0,508, p<0,001)$, farkına varma $(r=0,377$, $p=0,007)$ alt ölçek ve toplam $(r=0,574, \quad p<0,001)$ puanları arasında anlamlı bir ilişki saptandı. Yaş ile diğer ölçek puanları arasında anlamlı bir ilişki yoktu. DSM-5 Düzey-2 madde kullanım ölçeği ergen formu ile SOCRATES alt ölçek ve toplam puanları arasında anlamlı korelasyon saptanmadı. DSM-5 Düzey-2 madde kullanım ölçeği ergen formu ile BAPI-E madde kullanım özellikleri $(r=0,431, p=0,002)$, tanı $(r=460, p=0,001)$, şiddetli istek $(r=0,404, p=0,004)$ ve toplam puan $(r=0,411, p=0,003)$ arasında pozitif korelasyon saptandı. BAPI-E toplam puanı ile

\begin{tabular}{|c|c|c|c|}
\hline & & $\mathrm{N}$ & $\%$ \\
\hline \multirow[t]{4}{*}{ Madde ile ilk karşılaşma } & Arkadaş & 45 & 90 \\
\hline & Aile & 3 & 6 \\
\hline & Merak & 1 & 2 \\
\hline & $\begin{array}{l}\text { İç sıkıntısından } \\
\text { kurtulmak }\end{array}$ & 1 & 2 \\
\hline \multicolumn{4}{|l|}{ İlk kullandığı madde } \\
\hline & Sigara & 35 & 70 \\
\hline & Esrar & 15 & 30 \\
\hline \multicolumn{4}{|l|}{ Şu anda kullandığı madde } \\
\hline & Sigara & 50 & 100 \\
\hline & Esrar & 36 & 72 \\
\hline & Alkol & 28 & 56 \\
\hline & Metamfetamin & 17 & 34 \\
\hline & Ekstazi & 13 & 26 \\
\hline & Benzodiyazepin & 10 & 20 \\
\hline & Sentetik THC & 8 & 16 \\
\hline & Eroin & 6 & 12 \\
\hline & Uçucu madde & 3 & 6 \\
\hline & Kokain & 1 & 2 \\
\hline \multicolumn{4}{|l|}{ İdrar test sonucu } \\
\hline & Pozitif & 11 & 22 \\
\hline & Negatif & 39 & 78 \\
\hline
\end{tabular}




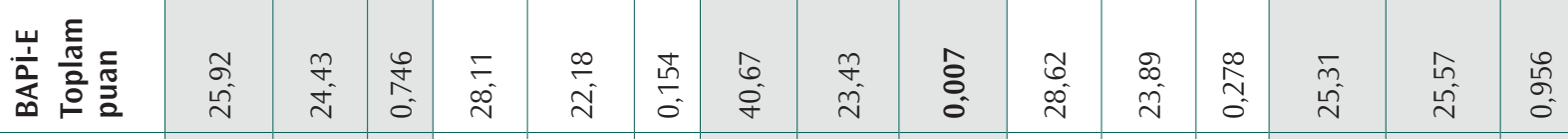

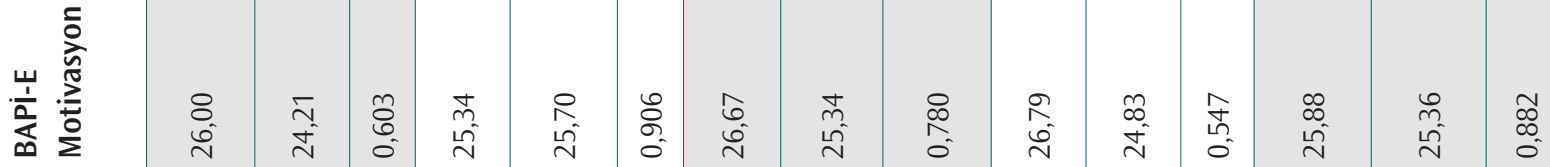

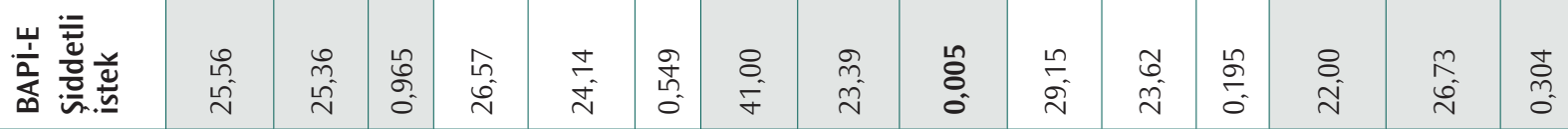

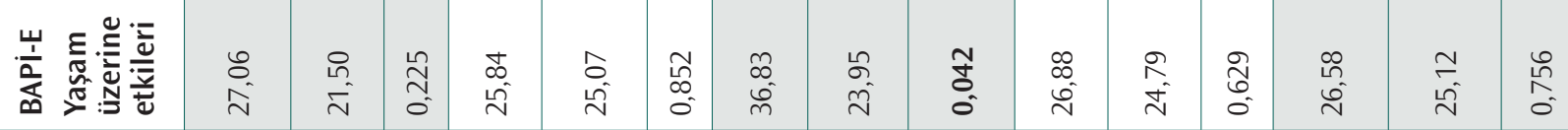

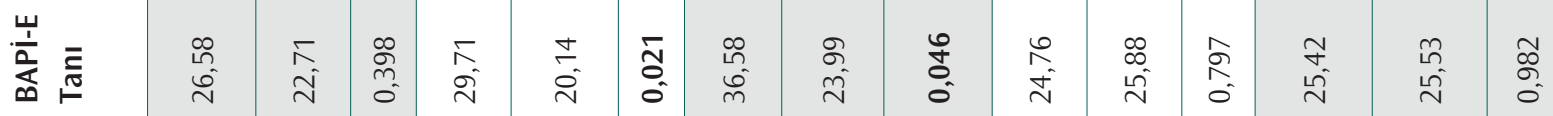

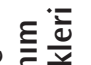

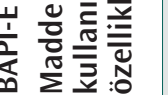

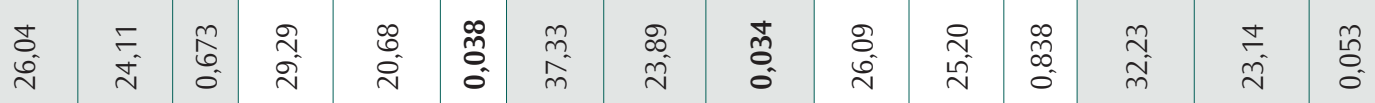

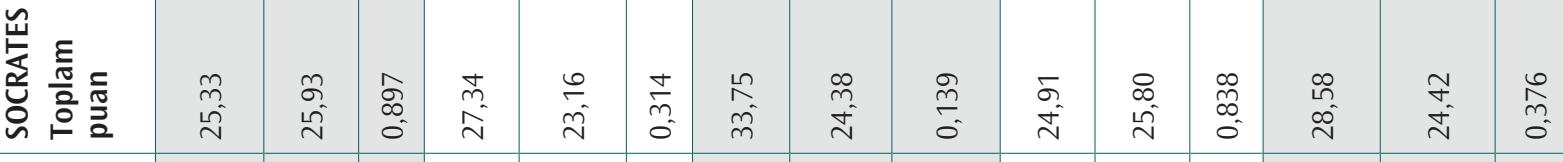

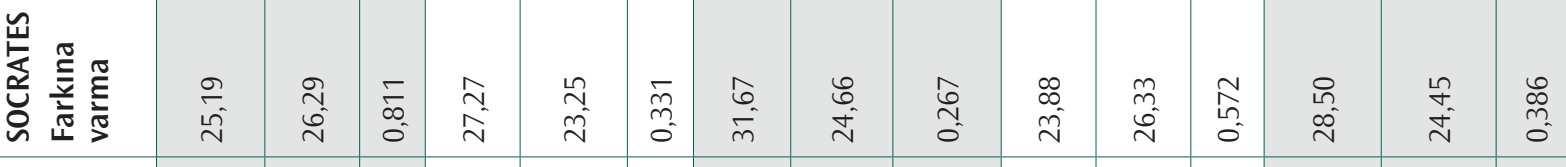

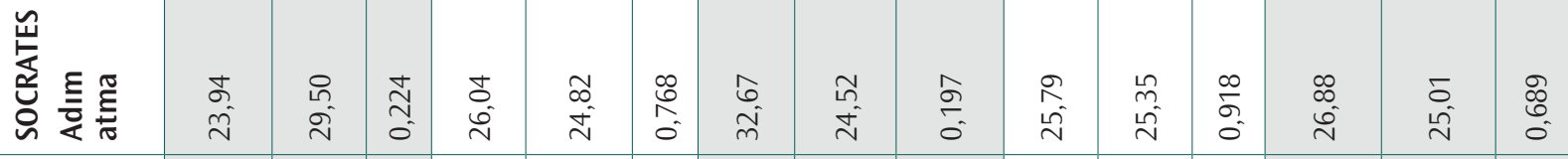

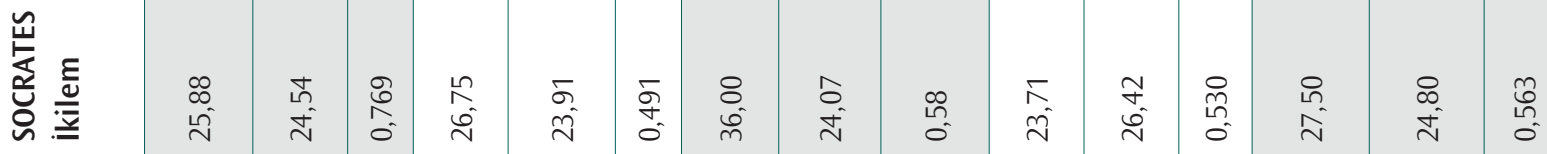

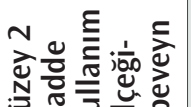
:

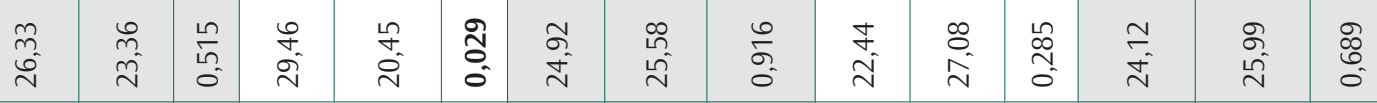
鸢 光语 西 드응

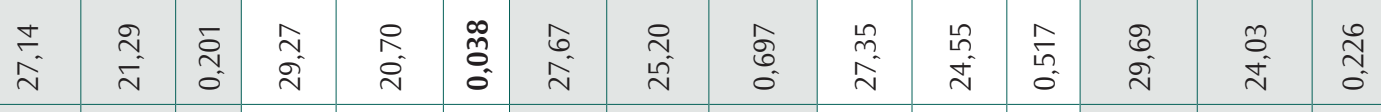

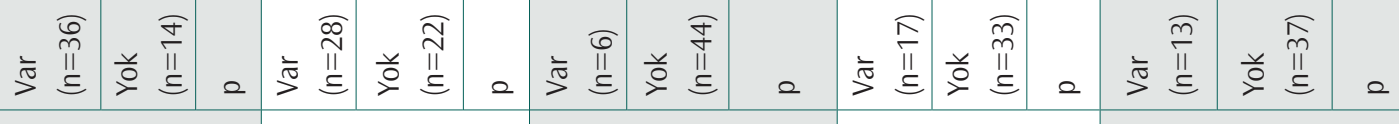

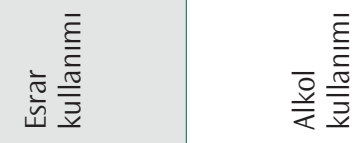

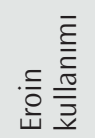

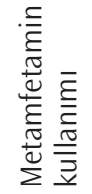


SOCRATES toplam puanı arasında ( $r=0,537, p<0,001)$, BAPI-E şiddetli istek ile SOCRATES ikilem alt ölçekleri $(r=0,351, p=0,012)$ arasında pozitif korelasyon saptandır. BAPI-E ile SOCRATES ölçeklerinin karșılaștııılması Tablo 4’te yer almkatdır.

\section{Tartışma}

Literatürde madde kullanımı açısından cinsiyetler arasında fark olmadığını bildiren yayınların yanı sıra $(22,23)$, erkeklerde daha sık olduğunu gösteren çalıșmalar da mevcuttur $(24,25,26)$. Çalışmamızda da erkek cinsiyet daha fazla idi ancak örneklemin oldukça küçük olması ve kontrol grubunun olması nedeni ile cinsiyet ile ilgili sonuçları genellemek mümkün değildir. Düșük akademik başarı ve okulu bırakmanın madde kullanımı için yüksek risk olușturduğu bilinmektedir (27). Atar ve arkadaşlarının çalışmasında (28) madde kullanan ergenlerin arasında okula devam etmeyenlerin oranı \%82 olarak bildirilmiștir. Bizim çalışmamızda da benzer olarak madde kullanan ergenlerin çoğunluğunun (\%68) okula devam etmediği gözlenmiștir. Ek olarak okula devam etmeyen madde kullanan ergenlerin, okula devam eden madde kullanan ergenlere göre daha șiddetli madde isteği bildirdikleri saptanmıștır. Okula devamın sağlanmasının hem maddeye başlama hem de kullanımı sürdürme açısından koruyucu olabileceği düşünülmektedir.

Toplum örneklemli bir çalışmada, 15 yașın altında madde kullanan ergenlerin \%90'ında en az bir psikiyatrik eș tanı olduğu, en sık davranım bozukluğu $(\% 72,4)$, DEHB $(\% 63,6)$ ve depresyon $(\% 52,7)$ eșlik ettiği rapor edilmiștir (29). Benzer olarak, yataklı
ÇEMATEM'de yürütülen bir çalışmada en sık eşlik eden psikiyatrik tanılar davranım bozukluğu $(\% 43,4)$, depresyon $(\% \% 20,6)$ ve DEHB $(\% 4,3)$ olarak bildirilmiștir $(23)$. Çalıșmamızda literatürle uyumlu șekilde en sık eșlik eden psikiyatrik tanılar davranım bozukluğu, DEHB ve depresyon olarak saptanmıștır.

Çalışmamızda ilk kez madde kullanma yaşı ülkemizde yapılan çalışmalara benzersaptanmıştır $(24,25,28)$. Çiftçivearkadaşlarının (24) çalıșmasında, 14 yaşın altında madde kullananların 15 yaşın üzerindekilere göre daha kısa sürede tedavi için bașvurdukları, tedavi için daha geç yașta bașvurmanın riski arttırdığı bildirilmiştir. Tedavi arayışı olan hastalarda çoklu madde kullanımının daha fazla ve madde kullanımının daha șiddetli olduğu gösterilmiștir (30). Bizim çalıșmamızda da benzer șekilde yaş ve bağımlııık șiddeti arttıkça madde kullanımını bırakma ve tedavi olma isteğinin arttığı gözlenmiștir. Bağımlılık geliștiğinin ve olumsuz etkilerinin farkında olunması ile madde kullanımını bırakma ve tedavi olma isteğinin arttığı düşünülmüştür. Çünkü çalıșmamızda benzer șekilde bağımlılık șiddetini değerlendiren ölçek (BAPI-E) ile tedavi isteğini değerlendiren ölçek (SOCRATES) arasında pozitif korelasyon saptanmıștır.

Ülkemizde ergenler arasında sigara kullanımı oldukça yaygın gözlenmektedir. Çeșitli illerde lise öğrencileri arasında yapılan çalışmalarda sigara içme oranı Ögel ve arkadaşları (31) tarafından $\% 55,9$, Uzun ve Kelleci (32) tarafından \%32,8 ve Karatay ve Baş (33) tarafından \%20 olarak bildirilmiștir. Çalıșmamızda tüm ergenlerin sigara kullandığı ve ilk kullandıkları maddenin ya sigara ya esrar olduğu saptanmıştır. Sigara kullanma oranının diğer çalışmalardan çok daha yüksek saptanması, bu çalışmanın

Tablo 4. BAPI-E ve SOCRATES ölçeklerinin korelasyon analizi

\begin{tabular}{|c|c|c|c|c|c|c|}
\hline & & & $\begin{array}{l}\text { SOCRATES } \\
\text { İkilem }\end{array}$ & $\begin{array}{l}\text { SOCRATES } \\
\text { Adım atma }\end{array}$ & $\begin{array}{l}\text { SOCRATES } \\
\text { Farkına varma }\end{array}$ & $\begin{array}{l}\text { SOCRATES } \\
\text { Toplam puan }\end{array}$ \\
\hline \multirow{12}{*}{ BAPI-E } & \multirow{2}{*}{ Madde kullanım özellikleri } & r & 0,434 & 0,283 & 0,372 & 0,375 \\
\hline & & $\mathrm{p}$ & 0,002 & 0,047 & 0,008 & 0,007 \\
\hline & \multirow{2}{*}{ Tanı } & r & 0,505 & 0,354 & 0,449 & 0,501 \\
\hline & & $\mathrm{p}$ & 0,000 & 0,012 & 0,001 & 0,000 \\
\hline & \multirow{2}{*}{ Yașam üzerine etkileri } & r & 0,369 & 0,204 & 0,239 & 0,360 \\
\hline & & $\mathrm{p}$ & 0,008 & 0,156 & 0,095 & 0,010 \\
\hline & \multirow{2}{*}{ Şiddetli istek } & $r$ & 0,351 & 0,146 & 0,268 & 0,278 \\
\hline & & $\mathrm{p}$ & 0,012 & 0,312 & 0,060 & 0,051 \\
\hline & \multirow{2}{*}{ Motivasyon } & r & 0,232 & 0,369 & 0,358 & 0,335 \\
\hline & & $p$ & 0,106 & 0,008 & 0,011 & 0,017 \\
\hline & \multirow{2}{*}{ Toplam puan } & r & 0,522 & 0,403 & 0,487 & 0,537 \\
\hline & & $\mathrm{p}$ & 0,000 & 0,004 & 0,000 & 0,000 \\
\hline
\end{tabular}


örnekleminin hastaneye başvuran ve madde kullanan ergenler olması ile açıklanabilmektedir. Ergenlerin esrarın sigaradan daha az zararlı olduğuna dair inanıșlarının olması (3), sigara ve esrarın birlikte kullanımını artırmaktadır ve bu da diğer maddelere geçiş kapısı olabilmektedir (34).

Literatür ile uyumlu olarak bu çalıșmada ergenlerin en sık kullandıkları maddeler sigara, esrar, alkol, metamfetamin ve ekstazi olarak saptanmıștır $(3,25,28)$. Uçucu madde kullanımı tedaviye başvuran ergenlerde yapılan önceki çalışmalardan (\%36 ila \%55) daha düşük seviyede bulunmuștur $(23,25,35)$. Alkol kullanım oranı ise diğer çalıșmalardan (\%28 ila \%44) daha yüksek bulunmuștur $(23,24,36)$. Bu farkın, çalıșmamızdaki örneklemin küçük olması ve bizim tedavi merkezimizin ayaktan hizmet veriyor olmasından kaynaklandığı düșünülmüștür.

Ergenlik, arkadaş ilișkilerinin ve bir gruba aidiyet hissinin ön planda olduğu bir dönemdir. Madde kullanan arkadașı olan ergenlerin, madde kullanan arkadașı olmayanlara göre madde kullanımı açısından 3 kat daha fazla risk taşıdıkları gösterilmiştir (37). Erken ve geç ergenlik dönemlerini kapsayan (10 yıllık) uzunlamasına bir çalışmada, madde kullanan arkadaș ile geçirilen zamanın sigara, alkol ve esrar birlikte kullanımını yordayan en önemli faktörlerden biri olduğu bildirilmiștir (38). Ülkemizde yapılan çalışmalarda da, ergenlerin ilk kez madde kullanmaya arkadaș aracılığı ile bașladıkları ifade edilmiștir $(23,32)$. Bizim çalıșmamızda da benzer şekilde ergenlerin çok büyük çoğunluğu ilk kez madde kullanmaya arkadaş aracılığı ile başladıklarını bildirmiştir.

Ergenin madde kullandığını ifade ettiği ya da şüphelenildiği durumlarda laboratuvar testi, çoğunlukla da idrar testi istenmektedir. Ailenin şüphelendiği, ergenin ifadesinin tutarsız olduğu durumlarda idrar testi objektif bir değerlendirme imkanı sağlasa da madde taraması için tek başına yeterli bir değerlendirme değildir (39). Çünkü maddelerin idrarda saptanma sürelerinin farklııı̆ı, doz, kronik kullanım, kullanan kișinin metabolizması gibi pek çok değişken idrar testi sonuçları etkileyebilmektedir (7). Ek olarak bazı sentetik maddeler de idrar testinde saptanmayabilmektedir. Bizim çalıșmamızda da madde kullandığını ifade eden 49 ergenden 10'unun ve kullanmadığını ifade eden 1 ergenin idrar testinde madde pozitifliği saptanmıștır.

Örneklem sayımızın çok küçük olması ve kontrol grubunun olmaması bu çalıșmanın kısıtılıklarındandır. Bu nedenle çalışma sonuçlarının madde kullanan ergen popülasyonuna genellenmesi mümkün olmayacaktır. Yine de ülkemizde hem ayaktan hem yataklı hizmet veren ÇEMATEM sayılarının az olması, bu alanda oldukça az çalıșma olması nedeni ile, bu çalışma literatüre önemli katkılar sağlamaktadır.

Ülkemizde de ciddi bir sorun olușturmaya devam eden ergenlerde madde kullanımının risk faktörlerinin iyi bilinmesi, riskli gruplara madde bağımlıı̆ğını önlemeye yönelik müdahaleler yapılması, madde kullanımını bırakma ve tedavi olma isteğini arttıran faktörlerin desteklenmesi madde ile mücadelede oldukça önem tașımaktadır. Bu konuda büyük örneklemli, uzunlamasına planlanacak, çok merkezli çalışmalara intiyaç duyulmaktadır.

\section{Kaynaklar}

1. Spear LP. Adolescent neurodevelopment. J Adolesc Health 2013; (2 Suppl 2): S7-S13.

2. Luna B, Marek S, Larsen B, et al. An integrative model of the maturation of cognitive control. Annu Rev Neurosci 2015; 38: 151-170.

3. Johnston LD, Miech RA, O'Malley PM et al. Monitoring the future national survey results on drug use: 1975-2018: Overview, key findings on adolescent drug use. Ann Arbor: Institute for Social Research. 2019, The University of Michigan.

4. Moss HB, Chen CM, Yi HY. Early adolescent patterns of alcohol, cigarettes, and marijuana polysubstance use and young adult substance use outcomes in a nationally representative sample. Drug Alcohol Depend 2014; 136: 5162.

5. Rowe CL, Liddle HA, Greenbaum PE, Henderson CE. Impact of psychiatric comorbidity on treatment of adolescent drug abusers. J Subst Abuse Treat. 2004; 26(2): 129-140.

6. Heradstveit O, Skogen JC, Hetland J, Hysing M. Alcohol and illicit drug use are important factors for school-related problems among adolescents. Front Psychol 2017; 8: 1023.

7. Gray KM, Squeglia LM. Research review: What have we learned about adolescent substance use? J Child Psychol Psychiatry 2018; 59(6): 618-627.

8. Squeglia LM, Fadus MC, McClure EA et al. Pharmacological treatment of youth substance use disorders. J Child Adolesc Psychopharmacol 2019; 29(7): 559-572.

9. Cservenka A. Neurobiological phenotypes associated with a family history of alcoholism. Drug Alcohol Depend 2016; 158: 8-21.

10. Leung RK, Toumbourou JW, Hemphill SA. The effect of peer influence and selection processes on adolescent alcohol use: A systematic review of longitudinal studies. Health Psychol Rev 2014; 8(4): 426-457.

11. Meier MH, Hall W, Caspi A, et al. Which adolescents develop persistent substance dependence in adulthood? Using population-representative longitudinal data to inform universal risk assessment. Psychol Med 2016; 46(4): 877-889.

12. Lee SS, Humphreys KL, Flory K, et al. Prospective association of childhood attention-deficit/hyperactivity disorder (ADHD) and substance use and abuse/dependence: A meta-analytic review. Clin Psychol Rev 2011; 31(3): 328-341.

13. Miettunen J, Murray GK, Jones PB, et al. Longitudinal associations between childhood and adulthood externalizing and internalizing psychopathology and adolescent substance use. Psychol Med 2014; 44(8): 1727-1738.

14. Emniyet Genel Müdürlüğü Narkotik Suçlarla Mücadele Daire Bașkanlığı. Türkiye Uyușturucu Raporu 2019. Ankara: T.C. Içișleri Bakanlığı, 2019

15. Emniyet Genel Müdürlüğü Narkotik Suçlarla Mücadele Daire Bașkanlığı. Türkiye Uyușturucu Raporu 2020. Ankara: T.C. İçișleri Bakanlı̆̆ı, 2020.

16. Emniyet Genel Müdürlüğü Narkotik Suçlarla Mücadele Daire Bașkanlığı. Türkiye Uyușturucu Raporu 2021. Ankara: T.C. Iççşleri Bakanlı̆̆ı, 2021.

17. Evren C, Ogel K, Demirci AC, et al. Prevalence of lifetime tobacco, alcohol and drug use among 10th grade students in Istanbul. Bull Clin Psychopharmacol 2014; 24(3): 201-210. 
18. Ünal F, Öktem F, Çetin Çuhadaroğlu F, et al. Okul Çağı Çocukları için Duygulanım Bozuklukları ve Șizofreni Görüșme Çizelgesi Şimdi ve Yașam Boyu Şekli DSM 5 Kasım 2016 Türkçe uyarlamasının (ÇDŞG-ŞY-DSM-5T) geçerlik ve güvenirliği. Turk Psikiyatri Derg 2019; 30(1): 42-50.

19. Ögel K, Evren C, Karadağ F, et al. Bağımlılık Profil İndeksi'nin (BAPi) geliștirilmesi, geçerlik ve güvenilirliği. Turk Psikiyatri Derg, 2012; 23(4): 264273.

20. Sapmaz ȘY, Sargın E, Ergin C. DSM-5 Düzey 2 Madde Kullanımı Ölçeğinin Türkçe formunun güvenirliği ve geçerliği. Bağımlılık Dergisi 2016; 17(3): 116122.

21. Evren C, Gurol DT, Ogel K, et al. Reliability and validity of Turkish Version the Stages of Change Readiness and Treatment Eagerness Scale (SOCRATES) in male substance dependent inpatients. Turk Psikiyatri Derg 2011; 22(Suppl.1): 70-71.

22. Merikangas KR, He JP, Burstein $M$, et al. Lifetime prevalence of mental disorders in US adolescents: results from the National Comorbidity Survey Replication-Adolescent Supplementation (NCS-A). J AmAcad Child Adolesc Psychiatry. 2010; 49(10): 980-989.

23. Bilaç Ö, Kavurma C, Önder A, et al. Bir bölge ruh sağlığı hastanesi çocuk ve ergen yataklı servisinde madde kullanımı nedeniyle yatarak tedavi gören gençlerin klinik ve sosyodemografik özellikleri. Klinik Psikiyatri Dergisi 2019; 22(4): 463-471.

24. Çiftçi Demirci A, Erdoğan A, Yalçın Ö, et al. Sociodemographic characteristics and drug abuse patterns of adolescents admitted for substance use disorder treatment in Istanbul. Am J Drug Alcohol Abuse 2014; 41(3): 212-219.

25. Yüncü Z, Aydin C, Coskunol H, et al. A sociodemographic evaluation of cases applying to a child and adolescent dependency centre during a period of two years attending ege university faculty of science. Bağımlılık Dergisi 2006; 7(1): 31-37.

26. Malta DC, Oliveira-Campos M, do Prado RR, et al. Psychoactive substance use, family context and mental health among Brazilian adolescents, National Adolescent School-based Health Survey (PeNSE 2012). Rev Bras Epidemiol 2014; 17(Suppl 1): 46-61.

27. Townsend L, Flisher A, King G. A Systematic review of the relationship between high school dropout and substance use. Clin Child Fam Psychol Rev 2007; 10(4): 295-317.
28. Atar AÖ, Yalçın Ö, Uygun E et al. Madde kullanım bozukluğu olan ergenlerde aile ișlevlerinin, çift uyumunun ve anne baba tutumunun değerlendirilmesi. Noro Psikiyatri Ars 2016; 53(1): 38-44.

29. Tanidir C, Ciftci AD, Doksat NG, et al. Trends and gender differences in substance use among children and youths admitted to an addiction treatment center in Turkey: Years 2011-2013. Klin Psikofarm Bulteni 2015; 25(2): 109-117.

30. Haughwout SP, Harford TC, Castle IJ, Grant BF. Treatment utilization among adolescent substance users: findings from the 2002 to 2013 National Survey on Drug Use and Health. Alcohol Clin Exp Res 2016; 40(8): 1717-1727.

31. Ögel K, Çorapçıŏlu A, Sır A, et al. Türkiye'de dokuz ilde ilk ve ortaöğretim öğrencilerinde tütün, alkol ve madde kullanım yaygınlı̆̆ı. Turk Psikiyatri Derg 2004; 15(2): 112-118.

32. Uzun S, Kelleci M. Substance abuse in high school students: their selfefficacy to avoid substance abuse and related factors. Dusunen Adam 2018; 31(4): 356-363.

33. Karatay G, Bas NG. Factors affecting substance use and self-efficacy status of students in eastern Turkey. Ciencia Saude Coletiva 2019; 24(4): 1317-1326.

34. Berg CJ, Payne J, Henriksen L, et al. Reasons for marijuana and tobacco couse among young adults: A mixed methods scale development study. Subst Use Misuse 2018; 53(3): 357-369.

35. Pumariega AJ, Burakgazi H, Unlu A et al. Substance abuse: risk factors for Turkish youth. Klin Psikofarm Bulteni 2014; 24(1): 5-14.

36. Yüncü Z, Bayram A, Altıntoprak E, et al. The assessment of substances preferred by the cases, who applied to the adolescent addiction center, based on the years. Bağımlılık Dergisi 2008; 9(2): 78-83.

37. Öztaș D, Kalyon A, Ertuğrul A, et al. Evaluation of risk factors affecting substance use among tenth-grade students. BioMed Res Int 2018; 2018: 1407649 .

38. D'Amico EJ, Rodriguez A, Tucker JS, et al. Early and late adolescent factors that predict co-use of cannabis with alcohol and tobacco in young adulthood. Prev Sci 2020; 21(4): 530-544.

39. Hadlan SE, Levy S. Objective testing: urine and other drug tests. Child Adolesc Psychiatr Clin N Am 2016; 25(3):549-565. 